\title{
PENGARUH PERAN KEPEMIMPINAN DAN PROMOSI JABATAN TERHADAP MOTIVASI KERJA YANG BERDAMPAK PADA PENINGKATAN KINERJA KARYAWAN PERUM PERURI KARAWANG
}

\author{
Oleh : \\ Eva Varida Natalina MS \\ Program Studi Magister Manajemen Fakultas Ekonomi dan Bisnis \\ Universitas Singaperbangsa Karawang \\ Email : epoycantiq@gmail.com
}

\begin{abstract}
ABSTRAK
Tujuan penelitian ini untuk memperoleh bukti-bukti empirik dan menemukan kejelasan fenomena serta kesimpulan tentang pengaruh peran kepemimpinan dan promosi jabatan terhadap motivasi kerja yang berdampak pada peningkatan kinerja karyawan Perum Peruri karawang.

Tesis ini diharapkan dapat memberikan sumbangan bagi pengembangan ilmu manajemen khususnya sebagai sumbangan pustaka ilmiah bidang manajemen sumber daya manusia, sebagai bahan referensi dalam penulisan ilmiah, sebagai bahan informasi, baik bagi pimpinan maupun rekan-rekan pada Dinas Kesehatan Kabupaten Karawang dalam pelaksanaan manajemen berbasis kinerja, sebagai bahan pertimbangan dan input dalam mengambil keputusan dan menentukan arah kebijakan.

Penelitian dilakukan dengan menggunakan metode kuantitatif dengan metode deskriptif dan verifikatif, yaitu: mengumpulkan, menyajikan, menganalisis dan melakukan pengujian hipotesis, serta membuat kesimpulan dan saran.

Berdasarkan hasil analisis penelitian, diperoleh kesimpulan sebagai berikut:

1. Korelasi kepemimpinan dengan promosi mempunyai nilai koefesien korelasi ( $r$ ) sebesar 0,568.Dengan demikian korelasi peran kepemimpinan dengan promosi jabatan memiliki tingkat korelasi sedang karena berada pada interval 0,40 - 0,599 (Sugiyono:2014:184) dan nilainya positif. Ini menunjukan bahwa jika kepemimpinan dengan promosi mampu meningkatkan kinerja karyawan jika dilakukan sesuai dengan prosedur yang baik dan benar.

2. Besarnya pengaruh kepemimpinan yang secara langsung berpengaruh terhadap motivasi karyawan adalah $23,43 \%$. Berdasarkan temuan penelitian ini dapat disimpulkan bahwa hipotesis penelitian yang menyatakan "kepemimpinan berpengaruh secara signifikan terhadap motivasi karyawan" dapat diterima.

3. Besarnya pengaruh promosi jabatan yang secara langsung berpengaruh terhadap motivasi kerja karyawan adalah 2,56\%. Berdasarkan temuan penelitian ini dapat disimpulkan bahwa hipotesis penelitian yang menyatakan "promosi jabatan berpengaruh secara signifikan terhadap motivasi kerja karyawan" dapat diterima.

4. Secara simultan kepemimpinan dan promosi berpengaruh secara signifikan terhadap peningkatan kinerja melalui motivasi karyawan sebesar $25,99 \%$. Sisanya yaitu sebesar $74,01 \%$ merupakan pengaruh yang datang dari faktor lain.

5. Besarnya pengaruh motivasi kerja karyawan terhadap kinerja karyawan adalah $14,44 \%$. Berdasarkan temuan penelitian ini dapat disimpulkan bahwa hipotesis penelitian yang menyatakan "motivasi berkontribusi secara signifikan terhadap kinerja karyawan" dapat diterima.
\end{abstract}

Kata kunci : Peran Kepemimpinan, Promosi Jabatan, Motivasi, Kinerja Karyawan

44. 


\section{PENDAHULUAN}

Dalam era persaingan yang ketat, kompetensi yang dimiliki harus yang terbaik dari segi Sumber Daya Manusia (SDM), karena kelangsungan suatu organisasi sangat dipengaruhi oleh sumber daya manusia (SDM) yang ada baik kualitas maupun kuantitasnya. Oleh karena itu perusahaan harus mampu membentuk sumber daya manusianya untuk dapat terampil dan ahli dibidangnya sehingga tujuan perusahaan dapat tercapai sesuai dengan waktu yang telah ditetapkan. Sebab Sumber daya manusia yang pontensial apabila didayagunakan secara efektif dan efisien akan bermanfaat untuk menunjang gerak lajunya perusahaan (Koesmono, 2006).

Titik pangkal dalam upaya menunjang gerak lajunya perusahaan tersebut adalah dengan meningkatkan kinerja karyawan. Sebab peningkatan kinerja karyawan merupakan salah satu cara yang tepat dalam upaya pencapaian sasaran dan tujuan perusahaan. Peningkatan kinerja bisa dilakukan dengan berbagai cara sebagai faktor pendorong untuk mencapai hal tersebut. Secara teoritis, bahwa kinerja karyawan sangat dipengaruhi oleh banyak hal, antara lain seperti peran kepemimpinan, promosidan motivasi kerja yang dilakukan oleh atasan dalam lingkungan kerja.

Perusahaan Umum Percetakan Uang Republik Indonesia (Perum Peruri) adalah Badan Usaha Milik Negara (BUMN) yang ditugasi untuk mencetak uang rupiah (baik uang kertas maupun uang logam) bagi Republik Indonesia, sesuai dengan Peraturan Pemerintah Nomor 32 tahun 2006. Dengan memiliki visi yaitu menjadikan Perusahaan berkelas dunia di bidang integrated security printing and system. Tentunya untuk menjalankan visi tersebut kualitas SDM sangatlah memiliki peran vital dalam melakukan pekerjaannya tersebut, menurut Moehirono (2012:95) kinerja kayawan merupakan gambaran mengenai tingkat pencapaian pelaksanaan suatu program kegiatan atau kebijakan dalam mewujudkan sasaran, tujuan, visi, dan misi organisasi yang dituangkan melalui perencanaan strategis suatu organisasi. Kinerja dapat diketahui dan diukur jika individu atau sekelompok karyawan telah mempunyai kriteria atau standar keberhasilan sebagai tolok ukur yang ditetapkan oleh organisasi.

Seorang pemimpin adalah orang yang memberi inspirasi, membujuk, mempengaruhi, dan memotivasi kerja orang lain. Kemampuan untuk memberi inspirasi orang lain adalah unsur tertinggi dari kepemimpinan. Seorang pemimpin harus punya daya tarik personal atau menjadi suri tauladan agar bisa memberi inspirasi bagi orang lain. Membujuk adalah aspek penting lainnya dari seorang pemimpin. Dan organisasi memerlukan pemimpin bertanggungjawab yang mampu menjadi motor penggerak yang mendorong perubahan organisasi. Peran kepemimpinan yang tepat akan menimbulkan proses promosi jabatan kerja karyawan yang sesuai dengan penilaian kinerja karyawan itu sendiri.

Promosi (promotion) merupakan proses pemindahan karyawan dari suatu jabatan ke jabatan lain yang lebih tinggi, yang biasanya diikuti oleh tugas, tanggung jawab, wewenang, dan penghasilan yang juga lebih tinggi dari jabatan yang diduduki sebelumnya.berperan penting bagi setiap pegawai. Dengan demikian, promosi seharusnya akan memberikan status sosial (social status), wewenang (authority), tanggung jawab (responbility), serta penghasilan (outcomes) yang semakin besar bagipegawai. Secara teoritis, apabila setiap pegawai memiliki akses atas promosi berdasarkan asas keadilan dan objektivitas, pegawai akan terdorong untuk lebih giat bekerja, bersemangat, berdisiplin dan berprestasi kerja. Namun berdasarkan hasil pengamatan pada Perum Peruri masih ada pandangan pegawai terhadap penempatan pegawai pada saat promosi jabatan tidak sesuai dengan bidang keahlian yang dimiliki oleh pegawai tersebut.

Untuk lebih menggambarkan situasi yang terjadi di atas tersebut, berikut ini kami sajikan rekapitulasi jawaban responden dalam pra penelitian berupa kuesioner yang Penulis 
sebarkan pada karyawan Perum Peruri Karawang sebanyak 50 orang karyawan yang diambil secara acak. Pra penelitin ini dilakukan untuk melihat fenomena secara jelas terhadap pelaksanaan kepemimpinan, promosi jabata, motivasi kerja dan kinerja karyawan Perum Peruri Karawang saat ini :

Tabel 1. Rekapitulasi Jawaban Responden pada Lembar Prapenelitian

\begin{tabular}{|c|l|r|r|r|}
\hline \multirow{2}{*}{ NO } & \multirow{2}{*}{ VARIABEL } & \multicolumn{2}{|c|}{ REKAPITULA } & JUMLAH \\
\cline { 3 - 5 } & & \multicolumn{1}{c|}{ YA } & TIDAK & \\
\hline 1 & Peran & 11 & 39 & 50 \\
\hline 2 & Promosi Jabatan & 16 & 34 & 50 \\
\hline 3 & Motivasi Kerja & 9 & 41 & 50 \\
\hline 4 & KINERJA & 18 & 32 & 50 \\
\hline \multicolumn{2}{|l}{ Sumber: Data Jawaban Responden Pada Prapenelitian 2017} \\
\hline
\end{tabular}

Dari data tabel 1 di atas dapat dilihat bahwa rata-rata responden menjawab pilihan TIDAK. Artinya bahwa ke-4 hal tersebut memang benar belum dilakukan secara prosedural yang mengacu pada SOP perusahaan, padahal visi perusahaan sangat jelas yaitu menjadikan perusahaan berkelas dunia di bidang integrated security printing and system. Dimana untuk mencapai visi tersebut tentunya SDM yang ada harus berkualitas.

Dengan pemamparan tersebut, penelitian ini bertujuan untuk mengetahui dan menjelaskan "Pengaruh Peran Kepemimpinan Dan Promosi Jabatan Terhadap Motivasi KerjaYang Berdampak Pada Peningkatan Kinerja Karyawan Pada Perum Peruri Karawang”.

\section{TINJAUAN PUSTAKA}

\section{Manajemen}

Setiap kegiatan organisasi perusahaan dituntut adanya suatu manajemen yang baik agar kelangsungan hidup perusahaan dapat terus terjamin. Manajemen yang baik merupakan hasil cipta, rasa, karsa, pikiran, dan perbuatan manusia yang dapat menolong manusia dalam mencapai tujuannya. Manajemen adalah seni dan ilmu perencanaan, pengorganisasian, pengarahan, pengordinasian, dan pengawasan untuk mencapai tujuan yang ditentukan terlebih dahulu.

Definisi manajemen menurut Stoner dan Freeman (Silalahi, 2002 :4) adalah :

"Manajement is the process of planning, organizing, leading, and controlling the work of organization members and using all available organizational resources to reach stated organizational goals".

Sedangkan menurut Nitisemito (2000:9) definisi manajemen adalah sebagai berikut : Manajemen adalah suatu seni dan ilmu untuk mencapai tujuan melalui kegiatan orang lain.

Berdasarkan sumber daya-sumber daya yang ada pada organisasi, maka manajemen dapat dibagi ke dalam manajemen sumber daya manusia, manajemen keuangan, manajemen produksi/operasi, manajemen pemasaran. Salah satu sumber daya yang memiliki peran penting dalam mencapai tujuan organisasi adalah sumber daya manusia, maka dari itu kita perlu membahas lebih mendalam tentang manajemen sumber daya manusia.

\section{Fungsi Manajemen}

Proses kegiatan-kegiatan manajemen tersebut terdiri dari :

a. Perencanaan(Planning)

Para manajer memikirkan kegiatan-kegiatan mereka sebelum dilaksanakan. Berbagai kegiatan ini biasanya didasarkan pada berbagai metode, rencana atau logika, bukan hanya atas dasar dugaan atau firasat.

b. Pengorganisasian(Organizing) 
Para manajer mengkoordinasikan sumber daya, sumber daya manusia dan material organisasi. Semakin terkoordinasi dan terintegrasi kerja organisasi, semakin efektif pencapaian tujuan-tujuan organisasi. Pengkoordinasian merupakan bagian vital pekerjaan manajer.

c. Pengarahan(Directing)

Para manajer mengarahkan, memimpin dan mempengaruhi bawahan. Manajer tidak melakukan semua kegiatan sendiri, tetapi menyelesaikan tugas-tugas melalui orangorang lain. Mereka juga tidak sekedar memberikan perintah, tetapi menciptakan iklim yang dapat membantu para bawahan melakukan pekerjaan secara paling baik.

d. Pengawasan(Controlling)

Para manajer berupaya untuk menjamin bahwa organisasi bergerak ke arah tujuantujuannya. Bila beberapa bagian organisasi ada pada jalur yang salah, manajer harus membetulkannya.

\section{Manajemen Sumber Daya Manusia}

Pada hakekatnya manajemen sumber daya manusia adalah pendayagunaan karyawan sebagai sumber utama dalam suatu organisasi atau perusahaan dengan cara yang paling efektif untuk mencapai suatu sasaran organisasi tersebut baik sasaran jangka pendek atau jangka panjang. Untuk mencapai itu, organisasi atau perusahaan harus terus menerus melaksanakan kegiatan mencari, menerima, menetapkan, mengembangkan, dan mendayagunakan pegawai secara efektif terencana dan terpadu. Manajemen sumber daya manusia sebenarnya adalah manajemen yang mengkhususkan dalam bidang sumber daya manusia atau bidang kepegawaian.

Manajemen sumber daya manusia sangat diperlukan untuk meningkatkan efektifitas sumber daya manusia dalam organisasi. Tujuannya adalah untuk memberikan kepada organisasi suatu kerja yang efektif, untuk mencapai tujuan ini manajemen sumber daya manusia akan menunjukkan bagaimana seharusnya instansi mendapatkan, mengembangkan, menggunakan, mengevaluasi, dan memelihara karyawan.

\section{Kepemimpinan}

Organisasi pada dasarnya dipastikan akan memerlukan seorang pemimpin. Keberhasilan atau kegagalan sebuah organisasi terletak pada kepemimpinan. Kepemimpinan terdapat di segenap organisasi dan tingkat paling kecil sampai dengan tingkat yang lebih tinggi. Menurut Sutrisno (2010:213) kepemimpinan adalah suatu proses kegiatan seseorang untuk menggerakkan orang lain dengan memimpin, membimbing, mempengaruhi orang lain, untuk melakukan sesuatu agar dicapai hasil yangdiharapkan. Dalam kerangka manajemen, kepemimpinan merupakan sub sistem dari pada manajemen. Karena mengingat peranan vital seorang pemimpin dalam menggerakan bawahan, maka timbul pemikiran di antara para ahli untuk bisa jauh lebih mengungkapakan peranan apa saja yang menjadi beban dan tanggung jawab pemimpin dalam mempengaruhi bawahannya.

\section{Dimensi dan Indikator Kepemimpinan}

Berikut ini adalah dimensi dan indikator kepemimpinan yang dijadikan sebagai acuan dalama penelitian ini :

a. Idealized Influence (kharisma) Mengarah pada perilaku kepemimpinan transformasional yang mana pengikut berusaha bekerja keras melebihi apa yang dibayangkan. Pemimpin karismatik memberikan visi dan misi, menanamkan kebanggaan, rasa hormat dan kepercayaan, dan menambah optimisme di antara bawahan.

Indikatornya adalah : rasa hormat dari karyawan, kepercayaan, dapat menjadi panutan

b. Inspirational Motivation (motivasi inspiratif) Pemimpin menggunakan berbagai simbol untuk memfokuskan usaha atau tindakan dan mengekspresikan tujuan dengan cara-cara 
sederhana. Pemimpin juga membangkitkan semangat kerja sama tim, antusiasme dan optimism diantara rekan kerja dan bawahannya.

Indikatornya adalah : motivator, penetapan tujuan

c. Individual Consideration (konsiderasi individual) Pemimpin transformasional memberikan perhatian khusus pada kebutuhan setiap individu untuk berprestasi dan berkembang, dengan jalan sebagai pelatih, penasihat, guru, fasilitator, orang terpercaya, dan konselor. Pemimpin mencoba untuk memotivasi bawahan untuk mencapai potensi mereka sepenuhnya melalui pelatihan, mentoring, dan menghubungkan kebutuhan individu untuk misi organisasi.

Indikatornya adalah : pengembangan karir, menciptakan lingkungan kerja yang baik dan hubungan dengan bawahan

d. Intellectual Simulation (stimulasi intelektual) Upaya memberikan dukungan kepada pengikut untuk lebih inovatif dan kreatih dimana pemimpin mendorong bawahan untuk menanyakan asumsi, menyediakan bawahan dengan ide-ide baru yang menantang dan membangkitkan kesadaran akan masalah, kesadaran pikiran mereka sendiri, dan pengakuan dari visi mereka di bawahan serta mengemukakan pendekatan lama dengan cara perspektif baru. Indikatornya adalah : ide kreatif dan problem solver.

\section{Promosi Jabatan}

Promosi jabatan merupakan proses pemindahan karyawan dari suatu jabatan ke jabatan lain yang lebih tinggi, yang biasanya diikuti oleh tugas, tanggung jawab, wewenang, dan penghasilan yang juga lebih tinggi dari jabatan yang diduduki sebelumnya. Dengan memberikan kesempatan promosi, berarti perusahaan melakukan usaha pengembangan karyawan melalui jenjang karir yang jelas, sehingga karyawan termotivasi untuk bekerja dan berprestasi sehingga kelangsungan operasional perusahaan akan lebih terjamin (Hasibuan, 2008).

Promosi jabatan adalah perpindahan dari suatu jabatan ke jabatan lain yang mempunyai status dan tanggung jawab yang lebih tinggi (Martoyo, 2007:71). Sedangkan menurut Hasibuan (2008:108) promosi jabatan adalah perpindahan yang memperbesar authoritydan responsibility karyawan ke jabatan yang lebih tinggi di dalam suatu organisasi sehingga kewajiban hak, status dan penghasilannya semakin besar. Lain halnya menurut Tohardi yang dikutip dari Flippo (2002:382) bahwa promosi jabatan adalah merupakan perubahan dari pekerjaan yang satu ke yang lain yang mempunyai syarat-syarat lebih baik dalam hal kedudukan dan tanggung jawab.

\section{Faktor-faktor Yang Mempengaruhi Promosi Jabatan}

Menurut Sondang P. Siagian (2009), syarat-syarat promosi adalah sebagai berikut:

1. Pengalaman. Dengan pengalaman yang lebih banyak diharapkan kemampuan yang lebih tinggi, ide-ide yang lebih banyak dan sebagainya.

2. Tingkat pendidikan. Ada juga perusahaan yang mensyaratkan minimal pendidikan untuk dapat dipromosikan pada jabatan tertentu. Alasannya adalah bahwa dengan pendidikan yang lebih tinggi diharapkan pemikiran yang lebih baik.

3. Loyalitas. Dengan loyalitas yang tinggi dapatdiharapkan antara lain tanggung jawab yang lebih besar.

4. Kejujuran. Untuk promosi jabatan-jabatan tertentu mungkin masalah kejujuran merupakan syarat yang penting. Misalnya untuk jabatan kasir pada umumnya syarat kejujuran merupakan syarat utama yang harus diperhatikan.

5. Tanggungjawab. Kadang-kadang sering kali suatu perusahaan diperlukan suatu tanggungjawab yang cukup besar, sehingga masalah tanggungjawab merupakan syarat utama untuk promosi jabatan. 
6. Kepandaian bergaul. Misalnya jabatan untuk salesman adalah sangat penting untuk menetapkan kepandaian bergaul sebagai suatu syarat promosi jabatan.

7. Prestasi kerja. Pada umumnya setiap perusahaan selalu mencantumkan syarat untuk prestasi kinerjanya.

8. Inisiatif dan kreatif. Untuk syarat promosi jabatan terhadap jabatan tertentu, mungkin syarat tingkat inisiatif dan kreatif merupakan syarat yang harus diperhatikan. Hal ini disebabkan karena untuk jabatan tersebut sangat diperlukan inisiatif dan kreatif.

\section{Dimensi dan Indikator Promosi Jabatan}

Menurut Simamora (2010) komponen dari promosi jabatan adalah sebagai berikut:

1. Kesempatan

Promosi jabatan di perusahaan harus memperhatikan kesesuaian antara latar belakang pendidikan dengan persyaratan jabatan yang ditetapkan oleh manajemen.

2. Kemampuan

Promosi jabatan di perusahaan harus dilakukan dengan mempertimbangkan pengalaman kerja dengan turut mempertimbangkan kreatifitas karyawan dalam bekerja.

3. Keadilan

Perusahaan harus melaksanakan promosi jabatan secara adil dengan memperhatikan kompetensi karyawan dan mempertimbangkan kinerja karyawan.

4. Prosedur

Promosi jabatan di perusahaan harus memiliki prosedur pelaksanaan yang baku dan dilakukan sesuai dengan prosedur.

\section{Motivasi Kerja}

Motivasi adalah keadaan jiwa dan sikap mental manusia yang memberikan energi, mendorong kegiatan atau gerakan dan mengarah atau menyalurkan perilaku ke arah mencapai kebutuhan yang memberikan kepuasan atau mengurangi ketidakseimbangan. Kebutuhan-kebutuhan tersebut timbul akibat dari hubungan antar manusia yang dlama hal ini lebih ditekankan pada hubungan yang terjadi didalam proses produksi yaitu hubungan industrial.Oleh karena itu motivasi kerja dapat diartikan sebagai bagian integral dari hubungan/industrial dalam rangka proses pembinaan, pengembangan, dan pengarahan sumber daya manusia dalam suatu perusahaan (Sinungan, 2008:134).

Sedangkan motivasi kerja adalah suatu kekuatan potensial yang ada dalam diri seorang manusia, yang dapat dikembangkannya sendiri atau dikembangkan oleh sejumlah kekuatan luar yang pada intinya berkisar sekitar imbalan moneter dan nonmoneter, yang dapat mempengaruhi hasil kinerjannya secara positif atau secara negatif, hal mana tergantung pada situasi dan kondisi yang dihadapi orang yang bersangkutan.

Menurut Mitchell (dalam Winardi , 2000) tujuan dari motivasi adalah memperediksi perilaku perlu ditekankan perbedaan- perbedaan antara motivasi, perilaku dan kinerja (performa). Motivasilah penyebab perilaku; andai kata perilaku tersebut efektif, maka akibatnya adalah berupa kinerja tinggi.

\section{Faktor-faktor Yang Mempengaruhi Motivasi kerja}

Faktor-faktor motivasi kerja Sihotang $(2007, p 245)$ berpendapat bahwa motivasi kerja melibatkan dua faktor:

A. Faktor-faktor individual:

a. Kebutuhan-kebutuhan

b. Tujuan-tujuan orang

c. Sikap-sikap

d. Kemampuan-kemampuan orang

B. Faktor-faktor organisasi :

a. Pembayaran gaji/upah

49.

Jurnal Manajemen \& Bisnis Kreatif 

b. Keslamatan kesehatan kerja
c. Para mandor (supervisi)
d. Para pengawas fungsional

\section{Dimensi dan Indikator Motivasi Kerja}

Berikut ini adalah dimensi dan indikator motivasi McClelland (Veirtzal Rivai, 2011) yang dijadikan sebagai acuan dalam dalam penelitian ini :

a. Kebutuhan berprestasi (Need for achievement), yang meliputi indikator berusaha melakukan sesuatu dengan cara baru dan kreatif, mencari feedback tentang perbuatannya, memilih resiko yang sedang dalam perbuatannya, mengambil tanggung jawab pribadi atas perbuatannya.

b. Kebutuhan berafiliasi (Need for affiliation), indikatornya adalah : menyukai persahabatan, mencari persetujuan atau kesepakatan dari orang lain, lebih suka bekerja sama daripada berkompetisi dan selalu berusaha menghindari konflik.

c. Kebutuhan untuk menguasai sesuatu (Need for power), indikatornya adalah menyukai pekerjaan dimana dia menjadi pemimpin, sangat aktif dalam menentukan arah kegiatan dari sebuah organisasi dimanapun dia berada dan senang dengan tugas yang dibebankan kepadanya.

\section{Kinerja Karyawan}

Secara etimologi, kinerja berasal dari kata prestasi kerja (performance). Sebagaimana dikemukakan oleh Mangkunegara (2005:67) bahwa istilah kinerja berasal dari kata job performance atau actual performance (prestasi kerja atau prestasi sesungguhnya yang dicapai seseorang) yaitu hasil kerja secara kualitas dan kuantitas yang dicapai oleh seorang pegawai dalam melaksanakan tugasnya sesuai dengan tanggung jawab yang diberikan kepadanya. Lebih lanjut Mangkunegara (2005:75) menyatakan bahwa pada umumnya kinerja dibedakan menjadi dua, yaitu kinerja individu dan kinerja organisasi. Kinerja individu adalah hasil kerja karyawan baik dari segi kualitas maupun kuantitas berdasarkan standar kerja yang telah ditentukan, sedangkan kinerja organisasi adalah gabungan dari kinerja individu dengan kinerjakelompok.

Menurut Mangkunegara (2005: 67), kinerja atau prestasi kerja adalah hasil kerja kualitas dan kuantitas yang dicapai oleh seorang pegawai dalam melaksanakan tugasnya sesuai dengan tanggung jawab yang diberikan kepadanya. Sedangkan menurut Gibson et.al. (2006:95) kinerja karyawan merupakan suatu ukuran yang dapat digunakan untuk menetapkan perbandingan hasil pelaksanaan tugas, tanggung jawab yang diberikan oleh organisasi pada periode tertentu dan relatif dapat digunakan untuk mengukur prestasi kerja atau kinerja organisasi.

\section{Faktor-faktor yang Mempengaruhi Kinerja Karyawan}

Dalam menjalankan fungsinya kinerja tidak berdiri sendiri, tetapi berhubungan dengan kepuasan kerja dan tingkat imbalan, dipengaruhi oleh keterampilan, kemampuan dan sifat individu. Oleh karena itu menurut model partner-lawyer kinerja individu pada dasarnya dipengaruhi oleh faktor - faktor :

a. Harapan mengenai imbalan

b. Dorongan

c. Kemampuan, kebutuhan dan sifat

d. Persepsi terhadap tugas

e. Imbalan internal dan eksternal

f. Persepsi terhadap tingakat imbalan dan kepuasan kerja

\section{Dimensi dan Indikator Kinerja Pegawai}

Menurut (Gomez, 2000:142) dimensi dari variabel kinerja karyawan adalah : 
1. Kualitas hasil pekerjaan, memiliki indikator :ketepatan waktu, ketelitian kerja, dan kerapian kerja

2. Kuantitas hasil pekerjaan, indikatornya adalah jumlah pekerjaan dan jumlah waktu yang dibutuhkan.

3. Pengertian terhadap pekerjaan, indikatornya adalah pemahaman terhadap pekerjaan dan kemampuan kerja

4. Kerja sama, indikatornya adalah kemampuan bekerja sama.

5. Kreatifitas, Merupakan kemampuan seorang pegawai dalam menyelesaikan pekerjaannya dengan cara atau inisiatif sendiri yang dianggap mampu secara efektif dan efisien serta mampu menciptakan perubahan-perubahan baru guna perbaikan dan kemajuan organisasi.

6. Kesadaran indikatornya adalah disiplin, tepat waktu dan kerja sama

7. Pengetahuan tentang pekerjaan, indikatornya adalah pendidikan, pengalaman dan lingkungan pekerjaan

8. InisiatifMelingkupi beberapa aspek seperti kemampuan untuk mengambil langkah yang tepat dalam menghadapi kesulitan, kemampuan untuk melakukan sesuatu pekerjaan tanpa bantuan, kemampuan untuk mengambil tahapan pertama dalam kegiatan.

Kualitas pribadi, indikatornya adalah menyangkut kepribadian, kepemimpinan, keramahtamahan dan integrasi pribadi.

\section{Kerangka Pemikiran}

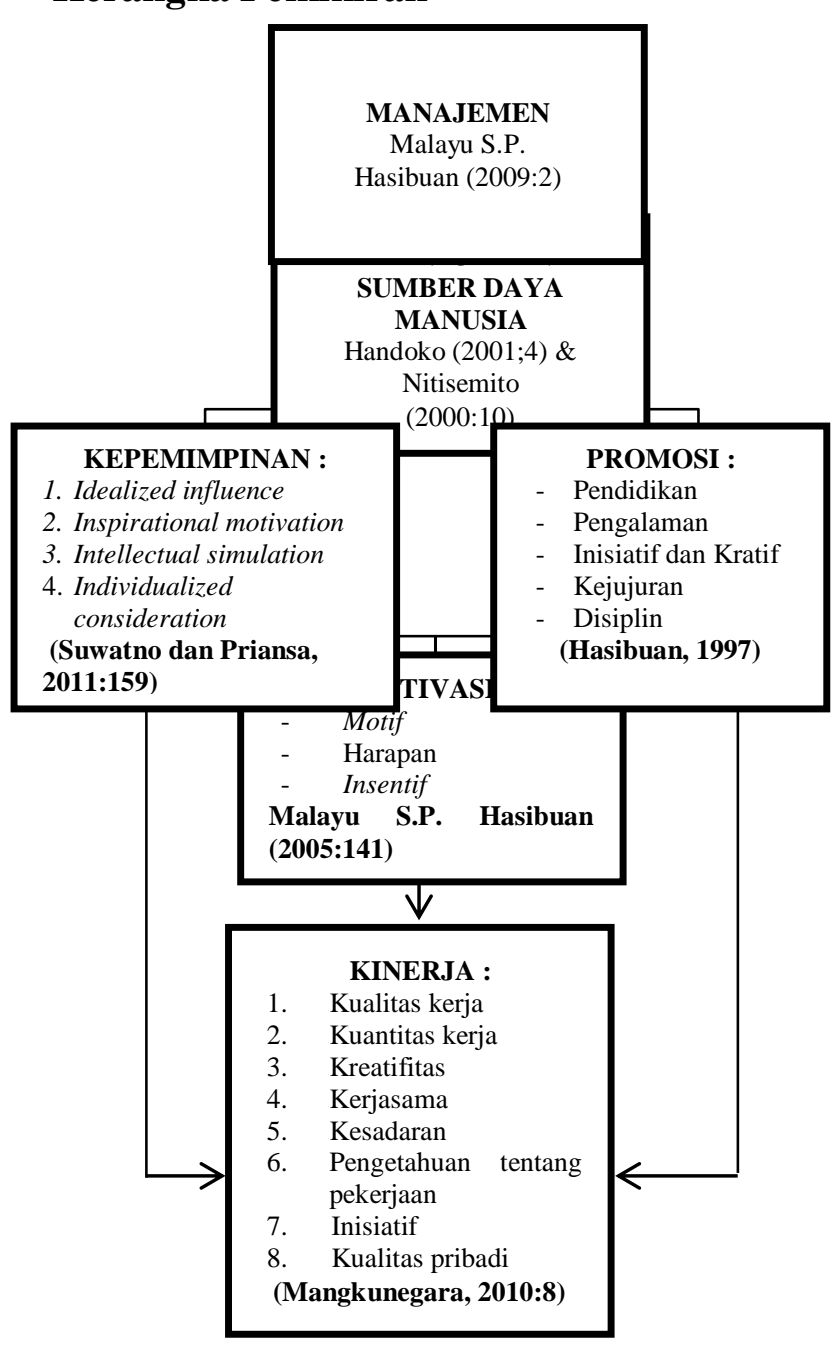

51. 


\section{Gambar 1. Kerangka Pikir Penelitian}

\section{Hipotesis Penelitian}

Berdasarkan kerangka pemikiran yang telah disajikan di atas, maka dapat diambil hipotesis bahwa diduga :

a. Terdapat korelasi antara kepemimpinan dengan promosi jabatan

b. Terdapat pengaruh kepemimpinan terhadap motivasi kerja karyawan pada Perum Peruri.

c. Terdapat pengaruhpromositerhadap motivasi kerja karyawan pada Perum Peruri.

d. Terdapat pengaruh secara simultan antara kepemimpinan dan promosi terhadap motivasi

e. Terdapat pengaruh motivasi terhadap kinerja karyawan Perum Peruri.

\section{METODOLOGI PENELITIAN}

Metode ini menggunakan pendekatan kuantitatif dengan cara menyebarkan kuesioner yang di ajukan kepada Karyawan Perum Peruri Karawang dengan pengolahan data menggunakan progaram SPSS. Sedangkan alat pengujian untuk menganalisis uji verifikatif menggunakan analisis Jalur (path analysis).

\section{Populasi dan sampel}

Populasi dalam penelitian ini adalah karyawan Perum Peruri Karawang yang berjumlah 3.137 orang. Dengan sampel yang digunakan pada taraf signifikansi $10 \%$ yaitu berjumlah 100 orang untuk dijadikan sempel dalam penelitian ini.

\section{Jenis dan Sumber Data}

Data adalah segala sesuatu yang diketahui atau dianggap mempunyai sifat bias memberikan gambaran tentang suatu keadaan atau persoalan (Supranto, 2001). Data yang digunakan dalam penelitian ini meliputi adalah data Primer. Data primer yang ada dalam penelitian ini merupakan penyebaran kuesioner.

\section{Metode Pengumpulan Data}

Metode pengumpulan data yang digunakan dalam penelitian ini adalah dengan metode Kuesioner.

\section{Uji Keabsahan Data}

Keabsahan data merupakan standar kebenaran suatu data hasil penelitian yang lebih menekankan pada data/informasi daripada dan jumlah orang. Pada dasarnya uji keabsahan data dalam sebuah penelitian hanya ditekankan pada uji validitas dan reliabilitas. Konsep untuk mengukur kualitas data, yaitu validitas dan reliabilitas. Penelitian akan menghasilkan kesimpulan yang tepat jika datanya valid dan reliable. Suatu instrumen yang reliable belum tentu valid, karenanya reliabilitas instrumen merupakan syarat untuk pengujian validitas instrumen. Oleh karena itu instrumen yang valid umumnya reliable, tetapi pengukuran reliabilitas instrumen perlu dilakukan.

Dengan kualitas data yang baik maka data yang terkumpul benar-benar menggambarkan fenomena yang ingin diukur. Sehingga dengan menggunakan instrumen yang valid dan reliable, maka hasil penelitian dapat dipertanggungjawabkan secara ilmiah.

\section{Rancangan Analisis Data}

\section{Analisis Deskriftif}


Analisis untuk menggambarkan atau mendeskripsikan kondisi variable kepemimpinan $\left(\mathrm{X}_{1}\right)$, promosi jabatan $\left(\mathrm{X}_{2}\right)$ terhadap motivasi kerja $(\mathrm{Z})$ yang berdampak pada kinerja $(\mathrm{Y})$ dengan menggunakan rentang skala.

Tabel 2. Analisis Rentang Skala

\begin{tabular}{|c|c|c|}
\hline Skala & Rentang skala & Kriteria \\
\hline 1 & $100,0-180,0$ & Sangat Tidak Setuju (STS)/ \\
\hline 2 & $180,1-260,0$ & Tidak Setuju (TS)/ Tidak \\
\hline 3 & $260,1-340,0$ & Cukup Setuju (CS)/ Cukup \\
\hline 4 & $340,1-420,0$ & Setuju (S)/Baik (B) \\
\hline 5 & $420,1-500,0$ & Sangat Setuju (SS)/ Sangat \\
\hline
\end{tabular}

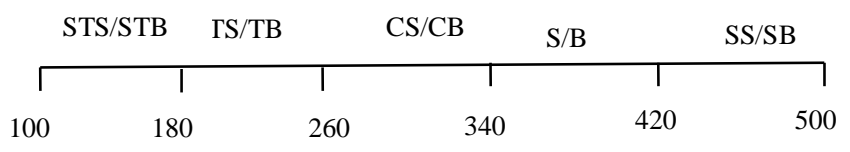

\section{Gambar 2. Rentang Skala}

\section{Analisis Verifikatif}

\section{Analisis Korelasi Product Moment}

Penelitian ini menggunakan analisis korelasi produk moment (Correlation product moment), analisis korelasi produk moment adalah salah satu pendekatan untuk mengetahui keeratan antara satu variabel dengan variabel lainnya dengan

$$
r=\frac{n \Sigma X Y-\Sigma X \Sigma Y}{\sqrt{\left(n \Sigma x^{2}-(\Sigma X)^{2}\right)\left(n \Sigma Y^{2}-(E Y)^{2}\right)}} \text { rumus : }
$$

$\begin{array}{lll}\text { Dimana : } & \\ \mathrm{r} & = & \text { Koefisien Korelasi } \\ \mathrm{x} & = & \text { Variabel Independen } \\ \mathrm{n} & = & \text { Jumlah Sampel } \\ \mathrm{y} & = & \text { Variabel dependen } \\ \text { Sumber : } & \text { Arikunto (2007:171) }\end{array}$

Dengan ketentuan bila $r_{s}=+1$ atau mendekati 1 , maka korelasi antara kedua variabel dikatakan positif dan sangat kuat sekali bersifat searah, bila $r_{s}=-1$, maka korelasi kedua variabel bersifat negatif sehingga kenaikan nilai-nilai Y yang sebaliknya.

\section{Analisis Determinasi}

Analisis koefisien determinasi digunakan untuk menentukan besarnya variasi dari kinerja yang dapat diterangkan oleh variabel budaya organisasi, motivasi dan komitmen.Koefisien determinasi dilambangkan dengan $\mathrm{R}^{2}$ merupakan proporsi hubungan $\mathrm{Y}$ dengan X. nilai koefisien determinasi adalah diantara 0 (nol) dan 1 (satu). Nilai $\mathrm{R}^{2}$ yang kecil berarti kemampuan variabel-variabel independen dalam menjelaskan variabel dependen amat kecil.Nilai yang mendekati 1 (satu) berarti variabel-variabel independen memberikan hampir semua informasi yang dibutuhkan untuk memprediksi variabel-variabel dependen. 


\section{Path Analiysis}

Analisis jalur (path analysis) digunakan untuk menganalisis pola hubungan antar variabel dengan tujuan untuk mengetahui pengaruh langsung maupun tidak langsung seperangkat variabel bebas (eksogen) terhadap variabel terikat (endogen).

Analisis jalur ini mengikuti pola struktural atau disebut model struktural (Kusnendi, 2005). Model struktural secara umum dapat digambarkan dengan persamaan sebagai berikut

$\mathrm{Y}_{1}=f\left(\mathrm{X}_{1}, \mathrm{X}_{2}, \ldots \mathrm{X}_{\mathrm{i}}\right)$

$\mathrm{Y}_{2}=f\left(\mathrm{X}_{1}, \mathrm{X}_{2}, \ldots \mathrm{X}_{\mathrm{i}}\right)$

$\mathrm{Y}_{\mathrm{k}}=f\left(\mathrm{X}_{1}, \mathrm{X}_{2}, \ldots \mathrm{X}_{\mathrm{i}}\right)$;

Diagram jalur dan persamaan struktural penelitian ini adalah seperti terlihat pada

Gambar 3 sebagai berikut :

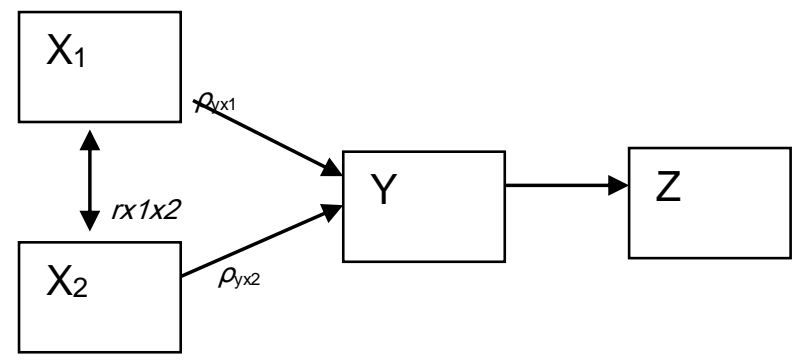

Gambar 3. Model Persamaan Analisis Jalur(Kusnendi, 2005)

Keterangan gambar 3 :

$\mathrm{X}_{1}=$ Kepemimpinan

$\mathrm{X}_{2}=$ Promosi

$\mathrm{Y} \quad=$ Kinerja

$\mathrm{Z}=$ Motivasi

$\varepsilon \quad=$ Epsilon yaitu menunjukkan variabel atau faktor residual yang menjelaskan pengaruh variabel lain yang telah teridentifikasi oleh teori, tetapi tidak diteliti atau variabel lainnya yang belum teridentifikasi oleh teori, atau muncul sebagai akibat dari kekeliruan pengukuran variabel (Kusnendi, 2005)

$r_{\mathrm{X}} \quad=$ Koefisien Korelasi

$\rho \quad=$ Koefisien Jalur

\section{Uji Hipotesis}

Untuk menguji koefisien jalur, terlebih dahulu harus menterjemahkan hipotesis penelitian ke dalam hipotesis statistik sebagai berikut :

\section{a. Uji t Korelasi}

Uji $t$ berarti melakukan pengujian terhadap koefisien korelasi. Pengujian ini dilakukan untuk mengetahui signifikansi peran secara hubungan antara variabel independen $\left(\mathrm{X}_{1}\right)$ dengan variabel independen $\left(\mathrm{X}_{2}\right)$ denganmengasumsikan bahwa variabel dependen lain dianggap konstan. Sugiyono (2010:250) merumuskan uji $t$ sebagai berikut:

Keterangan:

$$
t=\frac{r \sqrt{n-2}}{\sqrt{1-r^{2}}}
$$

$\mathrm{t}=$ Distribusi $\mathrm{t}$ 
$\mathrm{n}=$ Jumlah data

$r=$ Koefisien korelasi parsial

$r^{2}=$ Koefisien determinasi

$\mathrm{t}$ hasil perhitungan ini selanjutnya dibandingkan dengan $t_{\text {table }}$ dengan menggunakan tingkat kesalahan 0,05. Kriteria yang digunakan sebagai dasar perbandingan sebagai berikut :

Ho diterima jika nilai $-\mathrm{t}_{\text {table }}<\mathrm{t}_{\text {hitung }}<\mathrm{t}_{\text {table }}$

Ho ditolak jika nilai $t_{\text {hitung }}>t_{\text {table }}$ atau $t_{\text {hitung }}<-t_{\text {table }}$

Bila terjadi penerimaan Ho maka dapat disimpulkan suatu pengaruh adalah tidak signifikan, sedangkan bila Ho ditolak artinya suatu pengaruh adalah signifikan.

\section{b. Uji t (Pengujian Secara Parsial)}

Uji $t$ berarti melakukan pengujian terhadap koefisien regresi secara parsial. Pengujian ini dilakukan untuk mengetahui signifikansi peran secara parsial antara variabel independen terhadap variabel dependen denganmengasumsikan bahwa variabel independen lain dianggap konstan. Sugiyono (2010:250) merumuskan uji $t$ sebagai berikut:

$$
t=\frac{r \sqrt{n-2}}{\sqrt{1-r^{2}}}
$$

Keterangan:

$\mathrm{t}=$ Distribusi $\mathrm{t}, \mathrm{n}=$ Jumlah data

$r=$ Koefisien korelasi parsial

$r^{2}=$ Koefisien determinasi

$\mathrm{t}$ hasil perhitungan ini selanjutnya dibandingkan dengan $\mathrm{t}_{\text {table }}$ dengan menggunakan tingkat kesalahan 0,05 . Kriteria yang digunakan sebagai dasar perbandingan sebagai berikut :

Ho diterima jika nilai $-\mathrm{t}_{\text {table }}<\mathrm{t}_{\text {hitung }}<\mathrm{t}_{\text {table }}$

Ho ditolak jika nilai $t_{\text {hitung }}>t_{\text {table }}$ atau $t_{\text {hitung }}<-t_{\text {table }}$

Bila terjadi penerimaan Ho maka dapat disimpulkan suatu pengaruh adalah tidak signifikan, sedangkan bila Ho ditolak artinya suatu pengaruh adalah signifikan.

\section{c. Uji F (Pengujian Secara Simultan)}

Uji $\mathrm{F}$ adalah pengujian terhadap koefisien regresi secara simultan. Pengujian ini dilakukan untuk mengetahui pengaruh semua variabel independen yang terdapat di dalam model secara bersama-sama (simultan) terhadap variabel dependen. Menurut Sugiyono (2010:257) rumus pengujian adalah:

$$
F=\frac{R^{2} / k}{\left(1-R^{2}\right) /(n-k-}
$$

Keterangan :

$R^{2}=$ Koefisien determinasi

$k=$ Jumlah variabel independen,

$n=$ Jumlah data atau kasus

$F$ hasil perhitungan ini dibandingkan dengan $F_{\text {tabel }}$ yang diperoleh dengan menggunakan tingkat resiko atau signifikan level 5\% atau dengan degree freedom $=n-k-1$ dengan kriteria sebagai berikut:

Ho ditolak jika $F_{\text {hitung }}>F_{\text {tabel }}$

Ho diterima jika $F_{\text {hitung }}<F_{\text {tabel }}$ 
Jika terjadi penerimaan Ho, maka dapat diartikan sebagai tidak signifikannya model regresi berganda yang diperoleh sehingga mengakibatkan tidak signifikan pula pengaruh dari variabel-variabel bebas secara simultan terhadap variabel terikat.

\section{HASIL DAN PEMBAHASAN \\ HASIL PENELITIAN \\ Profil Responden \\ - Jenis Kelamin}

Tabel 3. Profil Jenis Kelamin

Responden Perum Peruri Karawang

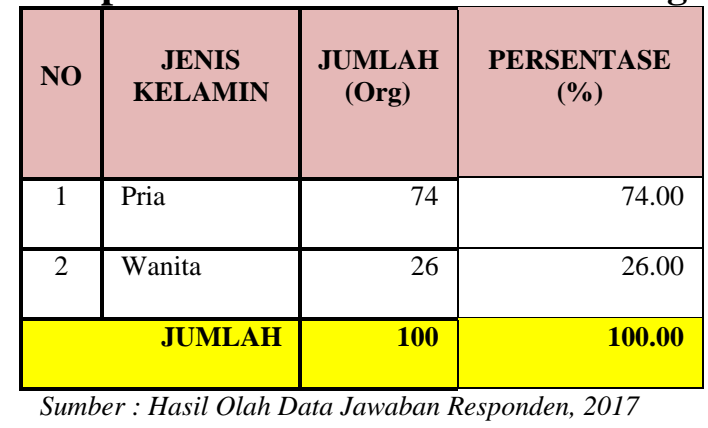

Berdasarkan Tabel 3 diketahui bahwa dari 100 responden terdapat 74 responden atau $74 \%$ adalah pria dan sisanya 26 responden atau $26 \%$ adalah perempuan. Berdasarkan data tersebut menunjukkan bahwa mayoritas responden adalah pria dengan jumlah 74 orang.

\section{- Tingkat Pendidikan}

Tabel 4 Profil Tingkat Pendidikan Responden Perum Peruri Karawang

\begin{tabular}{|c|l|r|r|}
\hline NO & \multicolumn{1}{|c|}{$\begin{array}{c}\text { TINGKAT } \\
\text { PENDIDIKAN }\end{array}$} & $\begin{array}{c}\text { JUMLAH } \\
(\mathbf{O r g})\end{array}$ & $\begin{array}{r}\text { PERSENTASE } \\
(\boldsymbol{\%})\end{array}$ \\
\hline 1 & S2 & 4 & 4,00 \\
\hline 2 & S1 & 23 & 23,00 \\
\hline 3 & D3 & 57 & 57,00 \\
\hline 4 & SLTA & 7 & 7,00 \\
\hline 5 & SLTP & $\mathbf{1 0 0}$ & $\mathbf{1 0 0 . 0 0}$ \\
\hline \multicolumn{2}{|c|}{ JUMLAH } & \\
\hline \multicolumn{2}{|l|}{ Sumber $:$ Hasil Olah Data Jawaban Responden, 2017 } \\
\end{tabular}

Berdasarkan data diketahui bahwa dari 100 responden karyawan Perum Peruri Karawang terdapat 57 responden atau 57\% memiliki tingkat pendidikan SLTA, 23 responden atau 23\% memiliki tingkat pendidikan Starata 1 (S1) dan 9 responden atau 9\% memiliki tingkat pendidikan Diploma. Berdasarkan data diatas maka mayoritas tingkat pendidikan responden adalah SLTA dengan jumlah 57 orang atau $57 \%$. 


\section{- Lama Bekerja}

Tabel 5 Profil Lama Bekerja Responden Perum Peruri Karawang

\begin{tabular}{|c|c|r|r|}
\hline NO & $\begin{array}{c}\text { MASA } \\
\text { KERJA (Thn) }\end{array}$ & $\begin{array}{c}\text { JUMLAH } \\
\text { (Org) }\end{array}$ & $\begin{array}{c}\text { PERSENTASE } \\
(\mathbf{\%})\end{array}$ \\
\hline 1 & 2 & 26 & 26,00 \\
\hline 2 & 4 & 35 & 35,00 \\
\hline 3 & 6 & 12 & 12,00 \\
\hline 4 & 8 & 11 & 11,00 \\
\hline 5 & 10 & 7 & 7,00 \\
\hline 6 & 12 & 9 & 9,00 \\
\hline \multicolumn{4}{|c|}{ JUMLAH } \\
\multicolumn{2}{|c|}{ Sumber : Hasil Olah Data Jawaban Responden, 2017 } \\
\hline
\end{tabular}

Berdasarkan data di atas diketahui bahwa dari 100 responden karyawan terdapat 26 responden atau $26 \%$ bekerja selama 2 tahun, 35 responden atau 35\% bekerja sudah bekerja selama 4 tahun. Dilihat dari lamanya kerja terdapat 9 orang atau 9\% yang sudah bekerja selama 12 tahun di Perum Peruri Karawang, namun jika dilihat dari Tabel tersebut di atas mayoritas karyawan sudah bekerja selama 4 Tahun.

\section{- Usia}

Tabel 6 Profil Usia Responden Perum Peruri Karawang

\begin{tabular}{|c|c|r|r|}
\hline NO & USIA (Thn) & $\begin{array}{l}\text { JUMLAH } \\
(\text { Org })\end{array}$ & $\begin{array}{c}\text { PERSENTASE } \\
(\%)\end{array}$ \\
\hline 1 & $19-24$ & 29 & 29,00 \\
\hline 2 & $25-30$ & 34 & 21,00 \\
\hline 3 & $31-36$ & 21 & 11,00 \\
\hline 4 & $37-41$ & 11 & 5,00 \\
\hline 5 & $42-47$ & 5 & $\mathbf{1 0 0 . 0 0}$ \\
\hline \multicolumn{2}{|c|}{ JUMLAH } & $\mathbf{1 0 0}$ & \\
\multicolumn{2}{|r|}{ Sumber : Hasil Olah Data Jawaban Responden, 2017 }
\end{tabular}

Berdasarkan Tabel 6 dari 100 responden, terdapat 29 responden atau 29\% berumur antara 19 - 24 tahun, 34 responden atau $34 \%$ berumur antara 25 - 30 tahun, 21 responden atau $21 \%$ yang berusia $31-36$ tahun, 11 responden atau $11 \%$ yang berusia $37-41$ tahun dan 5 responden atau 5\% yang berusia $42-47$ tahun. Berdasarkan data tersebut menunjukkan bahwa mayoritas usia karyawan antara 25 - 30 tahun dengan jumlah 34 orang.

\section{Hasil Pengujian Keabsahan Data}

\section{- Uji Validitas}

Tabel 7. Hasil Uji Validitas Variabel

\begin{tabular}{|c|l|c|}
\hline NO & \multicolumn{1}{|c|}{ VARIABEL } & KET. \\
\hline 1 & Kepemimpinan & Valid \\
\hline 2 & Promosi & Valid \\
\hline 3 & Motivasi kerja & Valid \\
\hline 4 & Kinerja Pegawai & Valid \\
\hline \multicolumn{2}{|c|}{ Sumber: Hasil Olah Data, 2017 } \\
\hline
\end{tabular}


Tabel 8. Hasil Uji Reliabilitas Variabel

\begin{tabular}{|c|l|c|c|l|}
\hline NO & \multicolumn{1}{|c|}{ VARIABEL } & $\begin{array}{c}\text { CRONBACH } \\
\text { ALPHA }\end{array}$ & $\begin{array}{c}\text { Nilai } \\
\boldsymbol{\alpha} \\
\text { Kritis }\end{array}$ & KET. \\
\hline 1 & Kepemimpinan $\left(\mathrm{X}_{1}\right)$ & 0.849 & 0,60 & Reliabel \\
\hline 2 & Promosi( $\left.\mathrm{X}_{2}\right)$ & 0.800 & 0,60 & Reliabel \\
\hline 3 & Motivasi Kerja (Z) & 0.850 & 0,60 & Reliabel \\
\hline 4 & Kinerja Karyawan (Y) & 0.951 & 0,60 & Reliabel \\
\hline
\end{tabular}

\section{- Uji Normalitas Data}

Tabel 9. Uji Normalitas Data

Sumber : Data Hasil Pengolahan SPSS, 2017

\begin{tabular}{|c|l|c|c|c|}
\hline No. & \multicolumn{1}{|c|}{ Variabel } & $\begin{array}{c}\text { Cronbach } \\
\text { Alpha }\end{array}$ & $\begin{array}{c}\text { Nilai } \\
\boldsymbol{\alpha}\end{array}$ & Keterangan \\
\hline 1 & Kepemimpinan $\left(\mathrm{X}_{1}\right)$ & 0.678 & 0,05 & Distribusi Normal \\
\hline 2 & Promosi $\left(\mathrm{X}_{2}\right)$ & 0.069 & 0,05 & Distribusi Normal \\
\hline 3 & Motivasi Kerja $(\mathrm{Z})$ & 0.058 & 0,05 & Distribusi Normal \\
\hline 4 & Kinerja Karyawan $(\mathrm{Y})$ & 0.061 & 0,05 & Distribusi Normal \\
\hline
\end{tabular}

\section{Analisis Deskriftif}

\section{- Kepemimpinan}

STS

TS

CS

$\mathrm{S}$

SS

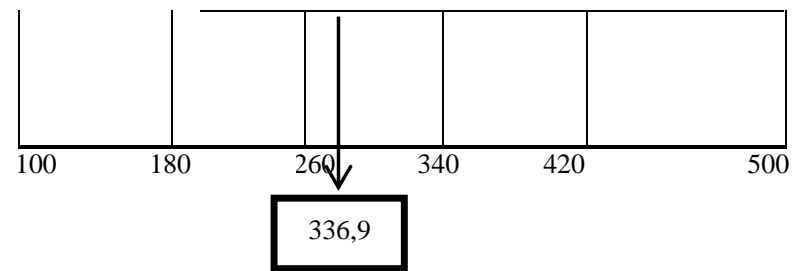

Total keseluruhan dari kuesioner tentang kepemimpinan yang dibagikan kepada 100 responden menghasilkan angka sebesar 3.369 dengan rata-rata sebesar 336,9. Angka tersebut berada pada interval pernyataan cukup setuju. Hal ini berarti bahwa terdapat cukup setuju karyawan terhadap pola kepemimpinan atasan di Perum Peruri Karawang dalam melaksanakan kepemimpinannya untuk menggerakan kinerja atau motivasi bawahan dalam bekerja.

\section{- Promosi Jabatan}

$\begin{array}{lllll}\text { STS } & \text { TS } & \text { CS } & \text { S } & \text { SS }\end{array}$

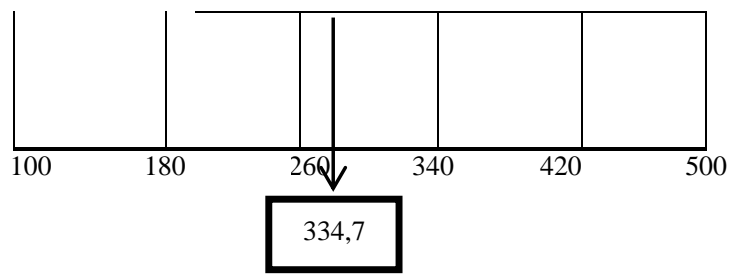

58. 
Total keseluruhan dari kuesioner tentang promosi ini yang dibagikan kepada 100 responden menghasilkan angka sebesar 2.343 dengan rata-rata sebesar 334,7. Angka tersebut berada pada interval pernyataan cukup setuju. Hal ini berarti bahwa terdapat cukup setuju karyawan terhadap pola pelaksanaan promosi di Perum Peruri Karawangoleh pihak perusahaan. Responden beranggapan bahwa pelaksanaan promosi haruslah sesuai dengan standar tentang pengangkatan karyawan sesuai dengan apa yang dibutuhkan dalam upaya meningkatkan hasil output produksi untuk bisa mencapai target yang ditetapkan.

- Motivasi Kerja

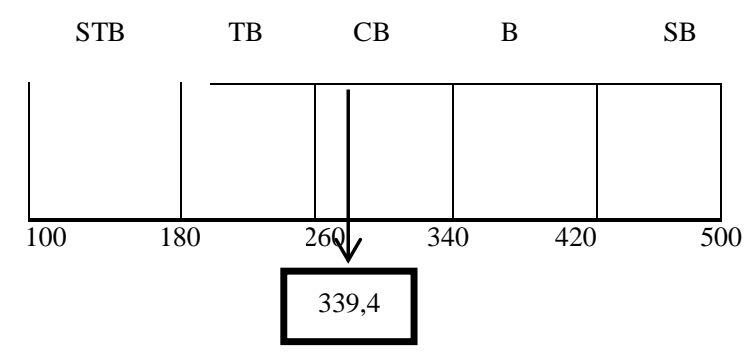

Total keseluruhan dari kuesioner tentang motivasi ini yang dibagikan kepada 100 responden menghasilkan angka sebesar 2.715 dengan rata-rata sebesar 339,4. Angka tersebut berada pada interval pernyataan cukup baik. Hal ini berarti bahwa cara perusahaan dalam upaya memberikan motivasi karyawannya dalam bekerja di Perum Peruri Karawang cukup baik. Mengingat bahwa motivasi sangatlah penting diberikan kepada karyawan, maka pihak perusahaan harus bisa melakukan pola motivasi yang baik agar mampu meningkatkan kinerja karyawan dalam upaya meningkatkan output produksi untuk bisa mencapai target yang ditetapkan.

- Kinerja Pegawai

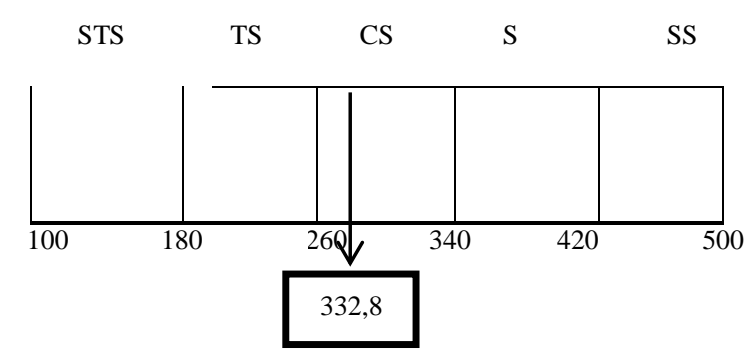

Total keseluruhan dari kuesioner tentang kinerja ini yang dibagikan kepada 100 responden menghasilkan angka sebesar 6.324 dengan rata-rata sebesar 332,8. Angka tersebut berada pada interval pernyataan cukup setuju. Hal ini berarti bahwa karyawan cukup setuju terhadap pola yang dilakukan oleh Perum Peruri Karawang dalam upaya meningkatkan kinerja karyawannya. Bila ini terus dibiarkan, maka apa yang diharapkan oleh pihak perusahaan terkait pencapaian target tak akan terwujud karena menurunnya kinerja karyawan yang terjadi saat ini di Perum Peruri Karawang.

\section{Analisis Verifikatif}

\section{- Analisis Korelasi}

Dari hasil analisis diperoleh besaran koefisien korelasi diantara variabel bebas yaitu kepemimpinan dengan promosi sebesar 0,568. Dengan demikian korelasikepemimpinan dengan promosi memiliki tingkat korelasi yang sedang dan nilainya positif dikarenakanberada di interval koefisien nilai 0,40 - 0,599: tingkathubungan yang kuat. (Sugiyono, 2014:184). 
- Analisis Jalur

1. Koefesien Jalur Antar Variabel

\begin{tabular}{|c|c|c|c|c|c|}
\hline \multicolumn{6}{|c|}{ Coefficients $^{\mathrm{a}}$} \\
\hline \multirow[t]{2}{*}{ Model } & \multicolumn{2}{|c|}{$\begin{array}{l}\text { Unstandardized } \\
\text { Coefficients }\end{array}$} & \multirow{2}{*}{\begin{tabular}{|c|}
$\begin{array}{c}\text { Standardized } \\
\text { Coefficients }\end{array}$ \\
Beta \\
\end{tabular}} & \multirow[t]{2}{*}{$\mathrm{t}$} & \multirow[t]{2}{*}{ Sig. } \\
\hline & B & $\begin{array}{l}\text { Std. } \\
\text { Error }\end{array}$ & & & \\
\hline $1 \quad$ (Constant) & 4.519 & 7.363 & & .614 & .541 \\
\hline Kepemimpinan & .789 & .186 & .388 & 4.251 & .000 \\
\hline Promosi jabatan & .323 & .334 & .085 & 1.965 & .037 \\
\hline Motivasi & 1.241 & .279 & .380 & 4.451 & .000 \\
\hline
\end{tabular}

a. Dependent Variable: Kinerja

Sumber : Hasil Pengolahan Data 2017

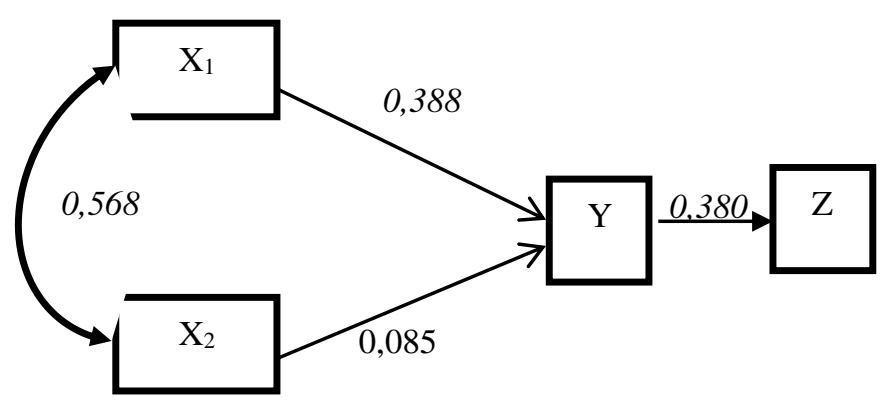

Analisis Jalur Antar Variabel

\section{Perhitungan Analisis Jalur Antar Variabel}

1. Variabel Kepemimpinan

a. Pengaruh langsung dari kepemimpinan terhadap motivasi yaitu :

$$
=0,388 \times 0,388=0,1505
$$

b. Pengaruh tidak langsung

Pengaruh tidak langsung darikepemimpinan terhadap kinerja melalui motivasi yaitu sebesar : $0,388(0,568) \times 0,380=0,0837$

c. Pengaruh Total

Pengaruh total yaitu gabungan daripengaruh langsung dan tidak langsung sebesar :

$0,1505+(0,388(0,568) \times 0,380)$

$=0,2343$

\section{Variabel Promosi Jabatan}

a. Pengaruh langsung dari promosi terhadap motivasi yaitu:

$=0,085 \times 0,085=0,0072$

b. Pengaruh tidak langsung

Pengaruh tidak langsung darikepemimpinan terhadap kinerja melalui motivasi yaitu sebesar : $0,085(0,568) \times 0,380=0,0183$

c. Pengaruh Total

Pengaruh total yaitu gabungan daripengaruh langsung dan tidak langsung sebesar : 
$0,0072+(0,085(0,568) \times 0,380)=0,0256$

Pengaruh Kepemimpinan dan Promosi Jabatan

Terhadap Motivasi

\begin{tabular}{|c|c|c|c|c|}
\hline \multirow{2}{*}{ Variabel } & $\begin{array}{c}\text { Koefesien } \\
\text { Jalur }\end{array}$ & $\begin{array}{c}\text { Pengaruh } \\
\text { Langsung }\end{array}$ & $\begin{array}{c}\text { Pengaruh } \\
\text { Tidak } \\
\text { Langsung }\end{array}$ & Sub \\
\cline { 3 - 5 } X1 & 0,388 & 0,1505 & 0,0837 & 0,2343 \\
\hline X2 & 0,085 & 0,0072 & 0,0183 & 0,0256 \\
\hline Total Pengaruh & $\mathbf{0 , 1 5 7 8}$ & $\mathbf{0 , 1 0 2 1}$ & $\mathbf{0 , 2 5 9 9}$ \\
\hline \multicolumn{7}{|l|}{ PengaruhVariabel Lain (8) } \\
\hline
\end{tabular}

Dengan demikian, pengaruh secara simultan variabel kepemimpinan $\left(\mathrm{X}_{1}\right)$ dan promosi $\left(\mathrm{X}_{2}\right)$ terhadap kinerja pegawai (Y) melalui motivasi (Z) adalah sebesar 25,99\%

3. Pengaruh $\mathrm{Y}$ terhadap $\mathrm{Z}$

Pengaruh langsung dari motivasi terhadap kinerja yaitu :

$0,380 \times 0,380=0,144$

\section{Uji Hipotesis}

1. Korelasi Antara Kepemimpinan dengan Promosi

Dengan harga $t_{\text {hitung }}=6,832$ yang selanjutnya dibandingkan dengan $t_{\text {tabel }}$ pada tingkat kesalahan $5 \%, \mathrm{db}=\mathrm{n}-2=100-2=98$, maka diperoleh $\mathrm{t}_{\text {tabel }}=1,980$. Dengan demikian diketahui $t_{\text {hitung }}(6,832)>t_{\text {tabel }}(1,980)$, maka dapat dinyatakan bahwa $\mathrm{H}_{\mathrm{o}}$ ditolak, artinya ada hubungan yang signifikan antara peran kepemimpinan dengan promosi jabatan.

2. Pengaruh Kepemimpinan terhadap Motivasi karyawan

Untuk pengaruh peran kepemimpinan secara parsial terhadap motivasi kerja karyawan dengan tingkat signifikan $(\alpha)=5 \%$, degree of freedom $(\mathrm{df})=(\mathrm{n}-2)=100-2=98$ diperoleh $\mathrm{t}_{\text {tabel }}=1,980$. Berdasarkan Tabel 4.25 di atas, menunjukan bahwa $\mathrm{t}_{\text {hitung }}=3,734$ dan sig. 0,000 . Artinya bahwa nilai sig. $(0,000)<\alpha(0,05)$ dant $_{\text {hitung }}(3,734)>t_{\text {tabel }}(1,980)$ maka $\mathrm{H}_{\mathrm{o}}$ tolak. Dengan demikian dapat disimpulkan bahwa peran Kepemimpinan secara parsial berpengaruh terhadap motivasi kerja karyawan.

3. Pengaruh Promosi terhadap Motivasi Karyawan

Untuk pengaruh promosi jabatan secara parsial terhadap motivasi kerja karyawan dengan tingkat signifikan $(\alpha)=5 \%$, degree of freedom $(\mathrm{df})=(\mathrm{n}-2)=100-2=98$ diperoleh $\mathrm{t}_{\text {tabel }}=1,980$. Berdasarkan Tabel 4.25 di atas, menunjukan bahwa $t_{\text {hitung }}=2,522$ dan sig. 0,013 . Artinya bahwa nilai sig. $(0,013)<\alpha(0,05)$ dant $_{\text {hitung }}(2,522)>t_{\text {tabel }}(1,980)$ maka $\mathrm{H}_{\mathrm{o}}$ tolak. Dengan demikian dapat disimpulkan bahwa Promosi Jabatan secara parsial berpengaruh terhadap motivasi kerja karyawan.

4. Pengaruh variabel Simultan

Untuk pengaruh peran kepemimpinan dan promosi jabatan secara simultan terhadap motivasi kerja karyawan dengan tingkat signifikan $(\alpha)=5 \%$, degree of freedom $(\mathrm{df})=(\mathrm{n}-4)$ $=100-4=96$, diperoleh $\mathrm{f}_{\text {tabel }}=2,47$. Sedangkan $\mathrm{f}_{\text {hitung }}=35,428$ dan sig. 0,000. Artinya bahwa nilai sig. $(0,000)<\alpha(0,05)$ dan $f_{\text {hitung }}(35,428)>\mathrm{f}_{\text {tabel }}(2,47)$ maka $\mathrm{H}_{\mathrm{o}}$ ditolak. Dengan demikian dapat disimpulkan bahwa peran kepemimpinan dan promosi jabatan berpengaruh simultan terhadap motivasi dan kinerja karyawan.

5. Pengaruh Motivasi terhadap Kinerja

Untuk pengaruh motivasi kerja secara parsial terhadap kinerja karyawan dengan tingkat signifikan $(\alpha)=5 \%$, degree of freedom $(\mathrm{df})=(\mathrm{n}-2)=100-2=98$ diperoleh $\mathrm{t}_{\text {tabel }}=1,980$.

61. 
Berdasarkan Tabel 4.25 di atas, menunjukan bahwa $t_{\text {hitung }}=4,451$ dan sig. 0,000 . Artinya bahwa nilai sig. $(0,000)<\alpha(0,05)$ dant $_{\text {hitung }}(4,451)>t_{\text {tabel }}(1,980)$ makaHotolak. Dengan demikian dapat disimpulkan bahwa motivasi kerja secara parsial berpengaruh terhadap peningkatan kinerja karyawan.

\section{PEMBAHASAN}

\section{Deskriptif}

1. Variabel Kepemimpinan

Kepemimpinan memiliki 10 indikator berada pada rentang nilai 260 - 340 dengan kriteria cukup setuju, artinya pelaksanaan kepemimpinan di Perum Peruri dinilai oleh pekerja atau karyawan kurang baik dilaksanakan. Atau dapat dikatakan bahwa pola kepemimpinan yang dilakukan sekarang ini belum mampu meyakinkan bawahan untuk dapat dijadikan sebagai kepatutan dalam hal memimpin atau mengatur pekerjaaan dalam upaya mencapai target yang telah ditetapkan oleh perusahaan.

\section{Variabel Promosi Jabatan}

Promosi memiliki 7 indikator yang berada pada rentang nilai 260 - 340. Total keseluruhan dari kuesioner tentang promosi ini yang dibagikan kepada 100 responden menghasilkan angka sebesar 2.343 dengan rata-rata sebesar 334,7. Dan angka tersebut berada pada interval pernyataan cukup setuju. Sementara menurut Sastrohadiwiryo (2002:258) bahwa untuk melakukan promosi memiliki 9 kriteria yang harus dimiliki oleh seorang karyawan sebelum dilakukan promosi. Hal ini berarti bahwa karyawan cukup setuju terhadap pola pelaksanaan promosi di Perum Peruri Karawang.

3. Variabel Motivasi Kerja

Motivasi memiliki 8 indikator yang berada pada interval $340-420$. Hanya terdapat dua indikator saja menyatakan cukup baik akan motivasi tersebut dengan nilai 329 dan 327. Yaitu indikator tentang dampak motivasi terhadap pemenuhan kebutuhan dan indikator pemberian insentif kepada karyawan berupa penghargaan. Artinya bahwa apa yang dilakukan oleh Perum Peruri Karawang dalam upaya mendorong dan memotivasi karyawannya cukupbaik dilakukan dan atau belum bisa memperhatikan apa yang dikehendaki oleh karyawan. Dengan belum dijalankannya secara baik pola motivasi karyawan oleh perusahaan, maka pihak perusahaan harus bisa merubah pola atau cara dalam mengupayakan apa yang dikehendaki oleh karyawan agar mampu mendorong/termotivasi kerjanya sehingga apa yang dikehendaki oleh pihak perusahaan pun akan tercapai sesuai dengan harapan.

\section{Variabel Kinerja}

Kinerja memiliki 19 indikator yang berada pada skala nilai 260 - 340 dengan kriteria cukup setuju terhadap peningkatan kinerja, artinya Perum Peruri Karawang dalam meningkatkan kinerja karyawannya belum sesuai dengan prosedur yang sudah ada dan ditetapkan oleh pihak perusahaan sendiri. Sedangkan menurut Sudjono (2005) kinerja merupakan prestasi kerja yakni perbandingan antara hasil kerja yang secara nyata dengan standart kerja yang ditetapkan dalam melaksanakan tugasnya sebagai karyawan, dengan indikator pengukuran kinerja. Sementara kinerja yang terjadi pada karyawan Perum Peruri belum menunjukan peningkatan.

\section{Pembahasan Veripikatif}

\section{Besaran Korelasi}


Dari hasil analisis yang diperoleh didapat besaran koefisien korelasi antara variabel kepemimpinam dengan promosi jabatan yaitu sebesar 0,568. Dengan demikian korelasi kepemimpinan dengan promosi memiliki tingkat korelasi yang sedang dan nilainya positif dikarenakanberada di interval koefisien nilai 0,40 - 0,599 : Korelasi sedang (Sugiyono, 2014:184). Sedangkan dilihat dari hasil uji hipotesis dapat dinyatakan bahwa ada hubungan yang signifikan antara peran kepemimpinan dengan promosi jabatan hal tersebut dapat dilihat dari besaran thitung.

2. Pengaruh Parsial Kepemimpinan terhadap Motivasi

Pada alfa 5\%, pemberiaan kepemimpinan berpengaruh signifikan terhadap motivasi sebesar 0,2343 atau 23,43\% dan tingkat signifikansi sebesar 0,000. Dimana 0,000 lebih kecil dari 0,05. Hal ini berarti kepemimpinan berpengaruh signifikan terhadap motivasi kerja karyawan pada Perum Peruri Karawang. Berdasarkan nilai perhitungan analisis jalur pengaruh yang ditimbulkan variabel kepemimpinan terhadap motivasi karyawan secara langsung meskipun nilainya rendah yaitu sebesar 0,2343 atau 23,43\% (Sugiyono:2014,184). Pada penelitian ini terlihat ada pengaruh secara langsung yang diberikan faktor kepemimpinan terhadap motivasi karyawan Perum Peruri Karawang.

3. Perngaruh Parsial Promosi terhadap Motivasi

Pada alfa 5\%, pemberian promosi berpengaruh secara signifikan terhadap motivasi kerja karyawan dalam bekerja. Hal tersebut dapat dilihat dari hasil signifikansi sebesar0.0256 atau 2,56\% dan tingkat signifikan sebesar 0,013. Dimana 0,013 lebih kecil dari 0,05. Hal ini berarti promosi berpengaruh signifikan terhadap motivasi kerja karyawan pada Perum Peruri Karawang.

4. Pengaruh Simultan Antar Variabel

Dari hasil perhitungan di atas didapatkan nilai koefesien determinasi sebesar 0,2599 atau $25,99 \%$. Artinya bahwa kontribusi variabel kepemimpinan dan promosi terhadap motivasi serta kinerja karyawan sebesar 25,99\%, sedangkan sisanya sebesar $74,01 \%$ dipengaruhi faktor lain yang tidak diteliti dalam penelitian ini.Untuk pengaruh peran kepemimpinan dan promosi jabatan secara simultan terhadap motivasi kerja karyawan dengan tingkat signifikan $(\alpha)=5 \%$, degree of freedom $(\mathrm{df})=(\mathrm{n}-4)=100-4=96$, diperoleh $\mathrm{f}_{\text {tabel }}=2,47$. Besaran $\mathrm{f}_{\text {hitung }}$ yang dihasilkan sebesar 35,428 dansig. 0,000. Artinya bahwa nilai sig. $(0,000)<\alpha(0,05)$ dan $f_{\text {hitung }}(35,428)>f_{\text {tabel }}(2,47)$ maka $\mathrm{H}_{\mathrm{o}}$ ditolak. Dengan demikian dapat disimpulkan bahwa peran kepemimpinan dan promosi jabatan berpengaruh simultan terhadap motivasi dan kinerja karyawan.

\section{Pengaruh Motivasi Terhadap kinerja}

Pada alfa 5\%, motivasi berpengaruh signifikan terhadap peningkatan kinerja sebesar 0,1444 atau $14,40 \%$ dan tingkat signifikansi sebesar 0,000 dimana 0,000 lebih kecil dari 0,05. Hal ini berarti motivasi berpengaruh signifikan terhadap peningkatan kinerja karyawan pada Perum Peruri Karawang. Motivasi berpengaruh positif terhadap peningkatan kinerja karyawan Perum Peruri Karawang. Berarti semakin tinggi motivasi karyawan atas suatu pekerjaan maka akan semakin meningkatkan kinerjanya. Demikian juga sebaliknya, semakin rendah motivasi karyawan kinerja yang diinginkan.

\section{SIMPULAN DAN SARAN}

\section{SIMPULAN}

Berdasarkan hasil penelitian yang dilakukan pada Perum Peruri Karawang maka dapat disimpulkan hal-hal sebagai berikut : 
1. Kepemimpinan berada pada kriteria cukup setuju, akan tetapi belum bisa berjalan sesuai dengan prosedural yang ada di perusahaan.

2. Promosi jabatan berada pada kategori cukup setuju, artinya pelaksanaan promosi jabatan belum sesuai dengan standar baku yang ada.

3. Motivasi berada pada kriteria cukup baik. Artinya perlu dilakukan kembali tentang pola atau metoda pemberian motivasi terhadap karyawan.

4. Kinerja karyawan berada pada kriteria cukup setuju. Hal ini mengindikasikan bahwa manajemen harus bisa membuat formula baru agar mampu meningkatkan kinerja karyawan.

5. Korelasi kepemimpinan dengan promosi saling memiliki pengaruh sebesar 0,568. artinya bahwa kedua variabel independent tersebut memniliki tingkat hubungan yang sedang.

6. Kepemimpinan berpengaruh terhadap motivasi sebesar $23,43 \%$ dan promosi berpengaruh terhadap motivasi sebesar $2,56 \%$.

7. kepemimpinan dan promosi berpengaruh signifikan terhadap peningkatan kinerja melalui motivasi karyawan dengan persentase sebesar 25,99\%.

8. motivasi berpengaruh signifikan terhadap kinerja dengan persentase sebesar $14,44 \%$.

\section{SARAN}

Berdasarkan hasil pembahasan dan kesimpulan penelitian ini, maka disarankan hal-hal sebagai berikut :

1. Sikap pemimpin dalam bekerja hendaknya harus menciptakan lingkungan kerja yang baik, agar lebih meningkatkan kembali terciptanya suasana atau kondisi lingkungan kerja yang baik.

2. Pelaksanaan promosi jabatan, hendaknya dilakukan dengan melihat latar belakang pendidikan yang dimiliki oleh karyawan juga sifat karyawan itu sendiri.

3. Dalam upaya meningkatkan motivasi kerja, sebaiknya pihak manajemen memberikan penghargaan terhadap karyawannya agar bisa lebih giat lagi dalam bekerja serta pemberian bonus atau insentif kepada karyawan berprestasi.

4. Dalam upaya peningkatan kinerja karyawan, pihak perusahaan sebaikknya selalu mengingatkan tentang pedoman kerja yang baik dan sesuai dengan SOP

5. Penelitian lebih lanjut tentang variabel lainnya yang mempengaruhi variabel kinerja melalui motivasi pada Perum Peruri Karawang yang tidak diteliti dalam penelitian ini sehingga diharapkan fungsi dan sistem manajemen dapat berjalan lebih optimal.

\section{DAFTAR PUSTAKA}

Arfin Murti, (2012). “Menciptakan Sumber Daya Manusia Yang Handal Dengan Training, Coaching dan Motivation”. Sidoarjo :LaskarAksara.

Arikunto, Suharsimi. (2006). “Prosedur Penelitian, Suatu pendekatan Praktek". Jakarta: Rineka Cipta

Amirullah \& Haris Budiyono. 2004. Pengantar Manajemen. Yogyakarta :Graha Ilmu.

Anoraga, Pandji. 2000. Psikologi Kepemimpinan. Jakarta: Rineka Cipta.

As'ad, M. (2003), Psikologi Industri: Seri Sumber Daya Manusia, Liberty, Jogjakarta. 2004. Psikologi Industri. Yogyakarta: Liberty

Bangun, Wilson. (2012). Manajemen Sumber Daya Manusia. Jakarta : Penerbit Erlangga

Dubrin, Andrew. Leadership (Terjemahan). Edisi Kedua. Jakarta: Prenada Media,2006 
Ghozali, Imam. 2006. Aplikasi Analisis Multivariate dengan Program SPSS. Semarang: BP UNDIP.

Hasibuan, S.P Malayu, (2014). “Manajemen Sumber Daya Manusia”. Edisi Revisi, Jakarta :Bumi Aksara.

Heidjrachman, 2002. Manajemen Personalia, Cetakan Sepuluh. Penerbit : BPFE, Yogyakarta.

Gibson, James L, et.al. 2000. Organisasi: Perilaku, Struktur, Proses. Edisi Kelima. Alih Bahasa Djoerban Wahid Jakarta: Erlangga

H.M. Burhan Bungin, Metodologi Penelitian Kuantitatif, Jakarta: Prenada Media, 2005, hlm. 75

Hani Handoko, Manajemen Personalia dan Sumber Daya Manusia, edisi 2, Yogyakarta: BPFE, 2001, hlm. 69.

Indrawijaya, Adam Ibrahim. (2000). Perilaku Organisasi. Jakarta : Sinar Baru Algesindo.

Koesmono, H. Teman (2006) Pengaruh Budaya Organisasi Terhadap Motivasi dan Kepuasan Kerja serta Kinerja Karyawan Pada Sub Sektor Industri Pengolahan Kayu Skala Menengah Di Jawa Timur. JURNAL ANAJEMEN \& KEWIRAUSAHAAN, VOL. 7, NO. 2, SEPTEMBER 2005: 171-188.

Mangkunegara Prabu Anwar, (2008). “Manajemen SDM Perusahaan”. Edisi Dari TeoriKePraktik, bandung :Alfabeta.

Mathis, Robert L dan Jackson. 2006. Manajemen Sumber Daya Manusia. Jakarta: Salemba Empat

Martoyo, Susilo. 2007. Manajemen Sumber daya Manusia. Edisi 5. BPFE. Yogyakarta

Moeheriono. 2012. "Pengukuran Kinerja Berbasis Kompetensi”. Jakarta: Raja Grafindo Persada

Notoatmojo, Soekidjo, (2009). “Pengembangan Sumber Daya Manusia”. Jakarta : PT. Rineka Cipta.

Nitisemito, Alex. 2009. Manajemen Personalia. Jakarta: Ghalia Indonesia

Ridwan dan Kuncoro, (2007).“Cara Menggunakan dan memaknai Analisi jalur (Path Analysis)”. Bandung :Alfabeta.

Rivai, Veithzal. 2005. Manajemen Sumber Daya Manusia untuk Perusahaan : dari Teori ke Praktik. Jakarta : PT Raja GrafindoPersada.

Richard L. Daft. 2010. Era Baru Manajemen. Buku 1 dan 2.Jakarta :Salemba Empat

Priyanto, Duwi, (2008). “Mandiri Belajar SPSS”.Yogyakarta :Mediakom.

Purwanto,M. Ngalim, 2000. Administrasi dan Supervisi Pendidikan, Jakarta: Remaja Rosdakarya.

Simamora, Henry. (2004). “Manajemen Sumber Daya Manusia”. Yogyakarta : STIE YKPN.

Singarimbun Masri dan Efendi Sofian, (2006). "Metode Penelitian Survei”. Jakarta : LP3ES. 
Sutrisno, Edy. 2010. Manajemen Sumber Daya Manusia. Edisi 1. Cetakan Kedua. Prenada Media Group. Jakarta

Sugiyono, (2011). “Metode Penelitian Kuantitatif, Kualitatif dan R\&D”. Cetakan ke-14. CV. Alfabeta, Bandung.

Santoso, Singgih. (2004). "SPSS Versi 12”. Jakarta :Gramedia Pustaka Utama.

Simamora, Henry. (2006). "Manajemen Sumber Daya Manusia”. Yogyakarta : Sekolah Tinggi Ilmu Ekonomi YKPN.

Siagian, Sondang P. 2001. Manajemen Sumber Daya Manusia. Jakarta :Bumiaksara.

Sugiyono, (2009). “Metodologi Penelitian Bisnis”. Cetakan 13. CV. Alfabeta, Bandung.

Sinungan Muchdarsyah, 2008. Produktivitas Apa dan Bagaimana. Jakarta: PT Bumi Aksara

Stonner, James, A.F. 2002. Manajemen.Edisi II. Prenhalindo ; Jakarta

Tika, Moh. Pabundu.(2006). “Metodologi Riset Bisnis”. Jakarta: PT. Bumi Aksara.

T Hani Handoko, (2008). “Manajemen Personalia dan Sumber Daya Manusia”. Cetakan Ke 16, Yogyakarta.

Terry, R George.(2005). “Dasar-dasar Manajemen”. Cetakan Ke Sembilan, Jakarta : PT. Bumi Aksara.

Wibowo, (2005).“Manajemen Kinerja”. Jakarta : PT. Raja Grafindo Persada. -(2010). “Manajemen Kinerja”. Yogyakarta :GrahaIlmu.

Wilson Bangun, Manajemen Sumber Daya Manusia, Jakarta: Erlangga, 2012, hlm. 210-211

Winardi, 2007. Teori Organisasi dan Pengorganisasian. Divisi Buku Perguruan Tinggi

Wahjosumidjo. 1991. Kepemimpinan yang Efektif. Yogyakarta: BalaiPustaka.

\section{Sumber Jurnal :}

Antoni, Feri. 2006. Pengaruh Gaya Kepemimpinan Orientasi Tugas dan Orientasi Hubungan terhadap Motivasi Kerja dan Dampaknya pada Prestasi Kerja Pegawai Pengadilan Tinggi Tata Usaha Negara Surabaya, Tesis Universitas 17 Agustus Surabaya.

Brahmasari, Ida AyudanSuprayetno, Agus. 2008. PengaruhMotivasiKerja, KepemimpinandanBudayaOrganisasiTerhadapKepuasanKerjaKaryawansertaDampa knyapadaKinerja Perusahaan (Studikasuspada PT. Pei Hai International Wiratama Indonesia). jurnalmanajemendankewirausahaan, vol.10, no. 2, september 2008: 124135.

Ermayanti Dwi, Thoyib Armanu, 2001. Pengaruh Faktor Motivasi Terhadap Prestasi Kerja Karyawan Pada Kantor Perum Perhutani II Surabaya, Jurnal Fakultas Ekonomi Universitas Brawijaya Malang.

Farid Yuli, 2011. Pengaruh Motivasi Kerja Kepemimpinan dan Budaya Organisasi terhadap Kinerja Karyawan (Studi Kasus di PDAM Eks karisidenan Surakarta.

Rezki Ramadhanni, 2014, Pengaruh Pelaksanaan Promosi Jabatan Terhadap Semangat Kerja Karyawan Divisi Redaksi Pada Pt. Tribun Pekanbaru. Jurnal FISIP Volume 2 No.2 Oktober 2014. 
Sugisno. Pengaruh Motivasi Kerja Terhadap Kinerja Perusahaan dan Pencapaian Individu di Best Western Hotel Asean International Medan Sumatera Utara. Jurnal. (tidak dipublikasikan).

Tampubolon, Biatna. D. 2007. Analisis Gaya Kepemimpinan dan Faktor Etos Kerja Terhadap Kinerja Pegawai Pada Organisasi yang Telah Menerapkan SNI 19-90012001. Jurnal Standardisasi No. 9, Hal: 106-115.

Pradana, Martha A., Bambang Swasto, D. Hamid. 2013. Pengaruh gaya kepemimpinan transformasional dan transaksional terhadap kinerja karyawan. Jurnal Administrasi Bisnis, 4(1) : 4

Yahyo, Handoyo Djoko W \& Reni Shinta Dewi, 2013 , Pengaruh Motivasi Lingkungan Kerja, dan Kompensasi terhadap kinerja karyawan melalui semangat kerja karyawan (Studi Kasus pada karyawan Melalui produksi CV. Putra Jaya Sahitaguna, Semarang), Diponegoro Journal of social and politic Tahun 2013, Hal 1 - 12.

Yanuarmawan, Dion. 2012. Pengaruh Promosi Jabatan Terhadap Kinerja Karyawan Dikaji Menurut Teori Aldelfer. Jurnal Akuntansi Dan Ekonomi Bisnis, Vol.1. No.1. 